\title{
Review
}

\section{Agonistic mourning: Political dissidence and the Women in Black}

\author{
Athena Athanasiou \\ Edinburgh University Press, Edinburgh, 2017. Xii + 348 pp. ISBN \\ 9781474420150
}

Contemporary Political Theory (2019) 18, S8-S11. https://doi.org/10.1057/s41296-0170181-4; published online 5 December 2017

In Agonistic Mourning, Athena Athanasiou embeds an ethnography of the Belgrade Women in Black (Žene $u$ Crnom) in a dense framework of social and political theory, not only to understand the work undertaken by the collective, but also to think about how that work can help pose broader questions regarding sovereignty, memorialization, and the possibilities of dissidence. Founded in 1991, at the beginning of the wars of succession in the former Yugoslavia, Women in Black is an antimilitarist, antinationalist, feminist group, whose distinctive mode of protest, shared with other Women in Black groups, involves silent public vigils, the participants clad in black. For seven years, Athanasiou did field work with the group, spending extended time in Belgrade, participating in street actions, gatherings, and workshops; conducting extensive interviews with both long-term members who remember the wars, and younger ones who don't; and learning from, and reflecting upon, their history and their ways of framing their praxis. This book draws from those observations and reflections to unsettle and broaden some central threads of contemporary political theory: questions of sovereign power, the modern biopolitical state, mourning and justice, and perhaps most importantly, the question of an agonistic politics.

Drawing on theorists of the political as agon from Arendt to Mouffe and Honig, Athanasiou posits that the collective practice of Women in Black constitutes an agonistic approach to the political. Rereading theorists of agonism through the group's positioning in wartime and postwar Belgrade, however, has the effect of complicating the concept. Standing in silence, engaged in what one interview subject calls 'a cruel mourning... a mourning without sentimentality' (p. 89), and what Athanasiou, after Derrida, terms 'impossible mourning,' the vigils of the Women in Black challenge what it can mean to appear in public space, to engage in the life of the polis. In her introduction, Athanasiou explains that 'I was interested in the ways in which their account of political organization and self-determination did not seem to presuppose but rather decenter the regulatory identifications and

(C) 2017 Macmillan Publishers Ltd., part of Springer Nature. 1470-8914 Contemporary Political Theory Vol. 18, S1, S8-S11 
representational politics that typically sustain conceptions of political agency' ( $\mathrm{p}$. 21). The 'trademarks' of Women in Black's political practice, she argues, make legible this decentering: 'responsiveness, cross-border acts of grief, and becoming the enemy in the face of national mobilization' (p. 21). The stance of impossible mourning disrupts the nationalist narrative of war, by endlessly invoking without appropriating the unacknowledged and excluded others. The silence of the participants of Women in Black actions performatively underscores the limits of what can be said and heard in the public sphere, while rendering the silence articulate as such. As an avowedly feminist group that retains the word 'Women' in its name while including men, the collective insistently interrogates the militarized biopolitical state, the heteronormative gender frames of which sustain themselves in part through the mobilization of the figure of 'woman.' Refusing militarization during the war and the logic of the state grounded in ethnic distinction thereafter has frequently marked the members of the collective as traitors.

The book is divided into four chapters with an introduction and an epilogue. In the first chapter, 'Mourning Otherwise,' the author helpfully frames the political contexts of the dissolution of Yugoslavia and the emergence of Women in Black, noting the broad range of feminist organizations that preceded and continued alongside it. As her informants explain the painful quandaries of identification in the postwar context, indexing losses that are political, social, and intimate, Athanasiou outlines the themes of grievability, mourning, and testimony that will be tracked throughout her analyses. Two reigning forms of memory and memorialization characterize the postwar condition: on the one hand, a 'statecentered neoliberal governmentality of managing and normalizing the past... and the legal and traumatic realism of reconciliation' (p. 37). The Women in Black performatively enact their 'mourning otherwise' through a negotiation of and resistance to these poles: 'their enduring collective bodily presence evinces agonistic longing for a different way to inhabit and enact the political' (p. 37). That longing is bound to their practice of public mourning, a form of counter-memory that refuses allegiance to state memorialization and the logics of reconciliation alike. Athanasiou sees in the Women in Black's performance of public mourning a Derridean melancholia, keeping the other without appropriating her, keeping her an inappropriated other. The black-clad figures standing silently in the square simultaneously invoke and deconstruct the time-honored figure of the mourning mother/sister/wife and express a lack of gendered dutifulness, a disobedience to the claims of state and market. The second chapter, 'The Gendered Intimacies of the Nationalist Archive,' carries these themes forward to theorize in more depth the counter-memorializing work of the Women in Black; their form of inconsolable mourning 'works to delegitimize the monological bereavement mandated by the epistemic violence of national archiving' (p. 93). That bereavement functions to constitute a national ethno-subject, arisen from the demise of Yugoslavia; the silent mourning vigils of the Women in Black unsettle that subject, raising the specters of

(c) 2017 Macmillan Publishers Ltd., part of Springer Nature. 1470-8914 Contemporary Political Theory Vol. 18, S1, S8-S11 S9 
the losses deemed ungrievable by the official archive. It is in the third chapter, 'Spectral Spaces of Counter-Memory,' that Athanasiou unfolds the concept of agonistic mourning, drawing from her reading of Arendt, together with Derrida, to think about what it might mean to understand the activist practices of Women in Black as a form of participation in a public sphere of contention and debate that will not have them, to mark out what haunts the official public sphere, to "carve an expansive cartography of critical memory in the polis' (p. 173), here postwar Belgrade. Standing exposed in Republic Square, the Women in Black, as Athanasiou's informants tell her, have experienced invisibility or harassment by passers-by and police. The Republic Square, a space laden with historical and political memory, is a particularly powerful location for 'unsettling...the politics of memory' (p. 173). Here, Athanasiou suggestively draws upon the ancient concept of 'stasis,' as it has been discussed by the classicist Nicole Loraux and elaborated by other theorists, to illuminate the signal characteristic of Women in Black actions, as a bodily disposition in space that is also a struggle. In Chapter 4, 'Political Languages of Responsiveness,' this question of the bodily and the vocal receives a more detailed analysis; the chapter culminates the multiple threads of the book by attending to the performative dimension of Women in Black's practice, arguing that through their silent standing, Women in Black activism 'yields an account of the political subject's social becoming and unbecoming as a performative event of responsiveness to others within a specific constellation of power' (p. 226).

This is a powerful book in many ways: Athanasiou has accomplished something that is not to be underestimated in bringing a substantial archive of political, social, and anthropological theory to bear on her ethnography of Women in Black. The risk of this kind of work is that the theory will, however ironically in this case, outweigh the voices of the informants, which are compelling and often profound in the author's presentation; at times, it can seem here that this risk has not been averted entirely. Some passages and sentences call out for the disciplining hand of an editor. However, the net effect is that, rather than being overwhelmed by Athanasiou's theoretical archive, the voices and practices of the Women in Black of Belgrade recalibrate and vivify it, causing us to reflect on the theory in new ways, and teaching us a great deal about this particular activist network. The book raises questions of nation, state, gender, and the aftermath of disaster in ways that resonate with other geopolitical locations, and especially with this moment of rising ethno-nationalisms. It offers rich resources for reflection on the ways in which the boundaries between the affective and the political are regulated - and the ways in which particular modalities of dissent might challenge and disrupt that regulation. Perhaps most vitally, the work opens up important questions regarding the possibilities and limits of agonistic politics in the modern biopolitical state. The epilogue poses this haunting question that underwrites Athanasiou's reading of Women in Black: How can those who have been 'let die' - as Foucault memorably

S10 () 2017 Macmillan Publishers Ltd., part of Springer Nature. 1470-8914 Contemporary Political Theory Vol. 18, S1, S8-S11 
put it - or who have been erased from public memory or rendered as less than human be made to appear? Or, to borrow from Rancière, how under these conditions can 'the part of no part' speak?

Sara Murphy New York University, New York, NY 10003, USA sara.murphy@nyu.edu 